\title{
Problems of protection and restoration of historical monuments of L'viv built using Roman cement
}

\author{
Mykola Bevz \\ Katedra Konserwacji Zabytków, Wydziat Budownictwa i Architektury, Politechnika Lubelska, \\ e-mail:m.bevz@pollub.pl
}

\begin{abstract}
In article are shown examples allow confirming that Roman cement was widely used in Lviv in the second part of the $19^{\text {th }}$ century while erecting the public and residential buildings. The creating and develop a program on research, preservation and restoration of historical and architectural monuments, on which the architectural and ornamental finishing of facades was carried out with application of Roman cement is proposed.
\end{abstract}

Keywords: Roman cement, architectural monuments, preservation and restoration.

\section{Introduction}

In recent years, an international team of researchers implemented a special project to study monuments of architecture constructed using the so-called Roman cement (The EU-project ROCARE - Roman Cements for Architectural Restoration to New High Standards) under the promotion of prof. Johannes Weber [1]. That binder material was factory produced in Europe in the nineteenth and early twentieth century [2, p. 77-80]. According to our preliminary estimates, in Lviv was built hundreds of buildings with the use of this material. Roman cement - a material which is very well provided for decorating facades, allowing to perform complex and durable plastic composition. A rich plastic facade is typical for the historical architecture of the city of L'viv a long ago. For this reason, the use of Roman cement in buildings of L'viv had a good ground [3].

L'viv is a city that on the map of Central and East Europe in the $18^{\text {th }}$ - beginning of $20^{\text {th }}$ centuries - from 1772 to 1918 used to be included in the Austrian State. Therefore Austrian influences, architectural techniques and technology affected the architecture of Galicia especially in the nineteenth and early twentieth centuries. These influences according to the historians of arts came about yet much earlier than annexation of Galicia to Austria in 1772. One can observe the striking example of such influences in creative works of union of sculpture Johan Pinsel and architect Bernard Merderer (Meretyn), who are considered to be Austrians by origin or at least representatives of baroque artistic methods of the Austrian School (unfortunately, their origin and artistic biography have not been researched properly yet and only in recent years they arrested scientists' attention). Opulent baroque architecture and plastic arts carved in natural stone or wood have been creating till now the image, the face of the most eminent cities of Galicia - L'viv (St. Iura's Greec-Catholic Cathedral, the Liubomirski Palace, St. Martin Rom-Catholic Church), Horodenka 
(Rom-Catholic Church), Buchach (Town Hall, the Greec-Catholic Church of the Intercession and Rom-Catholic Church), Rom-Catholic Church in Hodovytsia and other objects) [4]. It is worth mentioning that this tradition of abundant finishing of façades with décor and sculptures is even deeply rooted, in particular in L'viv (Gothic - 2 Ruska St.; the Renaissance - Chapel of the Boims, Three Saints Chapel, façade at 23 Rynok Square, Black Building on 3 Rynok Square; baroque - the church of Dominican monastery and other $[4,5]$. These very abundant plastic arts of facades of residential building distinguish Galicia cities and L'viv from modest residential building in the centres of Italian cities (Udine, Perugia, Assisi, etc.), of Poland cities (Lublin, Chelm) and of Lithuanian cities (Kaunas, Panevežys) etc.

In our opinion, this ancient Galician tradition of abundant plastic arts and décor of facades in residential buildings in the late $19^{\text {th }}$ century favoured the use of Roman cement for producing the picturesque elements of buildings. Consummate characteristics of Roman cement, first and foremost, fast hardening and perfect resistance to weather impacts (being rather rigorous in Galicia) facilitated wide application of this material in the late $19^{\text {th }}$ century while performing construction works at more significant architectural objects. These were most likely architects and entrepreneurs from Austria, Germany and Poland, who popularized this material.

\section{Previous studies}

Our interest in this topic arose after scientific contacts with Professor Johannes Weber, head of several research projects about Roman cement. In collaboration with Professor Weber has managed two scientific workshops in L'viv, that were declared to enhance the study of monuments built with using Roman cement and draw attention to the needs of their restoration $[6,7,8,9,10]$.

Circle of scientists concerned themselves with this subject matter in L'viv is still very narrow: in there midst architect and restorer Kostiantyn Prysiazhnyi (covered this subject matter in one of his publications and provides the description of the technology for students of Architecture delivering the lectures in historical construction techniques), and professor M.Sanytskyi (record of it in publications of Herald of L'viv Polytechnic University in construction and inclusion of the topic in lectures on construction material studies for students of construction department) [11]. One can also mention the report of "Balko" Company that came across Roman cement in the top tier of bell tower of Armenian Church (historical monument of the $14^{\text {th }}$ century, restoration work of the top in $19^{\text {th }}$ century).

No specialized inventory of L'viv buildings aimed at discovering the application of Roman cement has not been made yet. It still remains vague how was the Roman cement used in L'viv - for molding and sculpture, plastering? The buildings with Roman cement in other cities of Galicia have not been researched yet. However, one can find them in Ivano-Frankivsk (former Stanislav), Drohobych, Sambir, Uzhgorod, Stryi and other cities. Thus, we lack the overall picture of availability of objects with Roman cement; their number entered to the historical monuments register has not been found out yet.

Accordingly, in Ukraine the technical state of historical monuments with Roman cement has not been studied; scopes and reasons for their destruction and other important issues have not been detected. Correspondingly, methodical recom- 
mendations on restoration of historical monuments, where the technologies with Roman cement were applied, have not been elaborated.

\section{Presentation of study materials}

We would like to corroborate these points and show several examples of L'viv historical monuments on which we managed to detect the application of Roman cement. We performed the inspections and probing on two presented objects. These objects belong to the building of L'viv Polytechnic University, so we can see the prospect for their professional restoration, though the state of these objects being very unsatisfactory today. Some more objects were included to my presentation on the basis of my visual examination. It would be reasonable to confirm the availability of Roman cement on them through profound researches.

The first object we would like to present is the building of the former Palace of Arts erected by the architect Fr. Skowron in collaboration with Gr. Peżański and M. Luzecki (sculptures by J. Markowski and A. Popel) at the upper terrace of Stryskyi Park [12, s. 112]. The building was projected as one of the objects of immense exhibit complex, so called Common Regional Exhibit, which was open in fall in 1894. It is a local architectural monument (fig. 1). After the World War II (when the Exhibit was liquidated and almost all pavilions were gradually dissembled) the inside of building was fully rebuilt to perform the sports function for L'viv Polytechnic University. In one wing there were gymnasiums arranged and in the other - a swimming pool. At present the technical state of the building is extremely poor. Our researches pursued in June 2009 determined that this building was erected with application of Roman cement (probing taken by M. Bevz, K. Prysiazhnyi). On our side we have suggested the Rector of Polytechnics not to commence the repair works and perform diligent examination of the object in order to elaborate the correct method of repair and restoration works. Considering these data, previously developed design documentation of building repair is being revised (the project was performed by the planning and design office of Polytechnics). In our judgment, the project did not meet the restoration requirements and needed further elaboration.

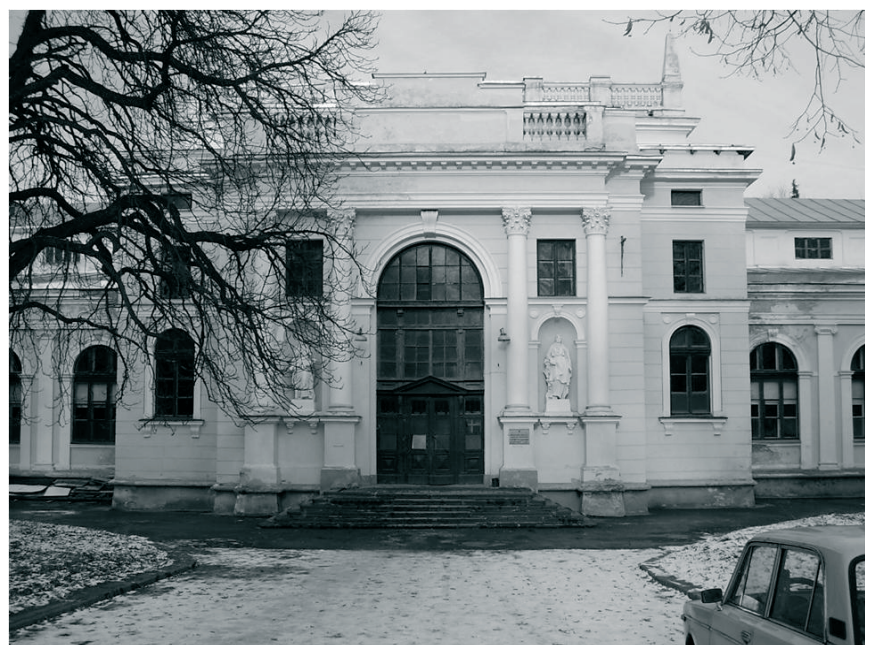

Fig. 1. The elevation of former Palace of Arts. Foto: M.Bevz, 2009. 


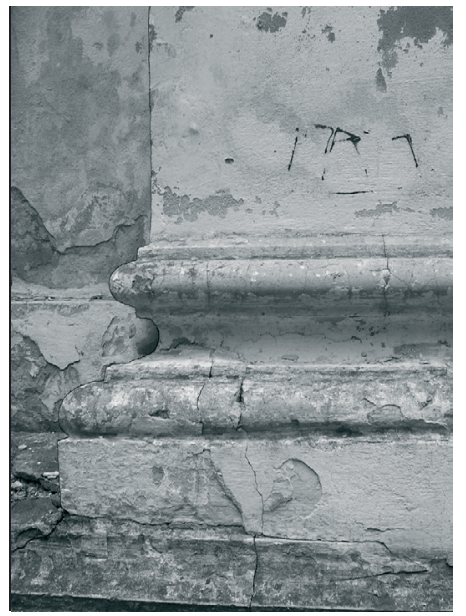

Fig. 2. The basis of pilaster made with using Roman cement. Foto: M.Bevz.

Roman cement was used by architect Franz Skowron while erecting the Palace of Arts to produce picturesque elements of facades (bases for pilasters and capitals, locking brackets, archivolts, cornices, railing posts, profiled components of window-ledge) and sculpture. Details of Roman cement were combined on facades with traditional limy plastering. We have ascertained two methods of producing the details from Roman cement at this object: a) use of Roman cement to produce compacted components at the very site; pulling method (cornice, bases of pilasters); this method is evidenced by the illustrating the transition of layer of roman cement from basis of pilasters over to level vertical surface of its body (fig. 2; b) mounting of prefabricated elements on façades (capitals, key brackets). Main reason for poor technical state of building is lack of repair of roofs and enduring blotting of walls and façade décor, inappropriate methods of previous repairs.

Second object is located in the very city centre at the beginning of Kniazia Romana St. (former name of Galytska St., at the end of the $19^{\text {th }}$ century S. Batory). Regional Court used to be situated in this building (it was also called "Palace of Justice"). The building was erected in the place of north wing of building of Barefoot Carmelite Monastery. It was built according to the project of architect F. Skowron in collaboration with architect Jan Zawieyski from Krakow [13, p. 275] (fig. 3, 4). L'viv sculptors Anton Popel and Leonard Marconi were also engaged in work on finishing the facades and interiors $[12, \mathrm{p} .116]$. The construction was commenced in 1891 and lasted till 1895; it is believed that while planning the building Jan Zawieyski was the one to choose the decorating forms of façade, as well as materials and construction techniques. We have not managed yet to find out the very plan of facade finishing by Jan Zawieyski [11, p. 275]. Sculptural group "Justice" above the front of main entrance performed in 1893 by Leonard Marconi. There used to be an opulently decorated courtroom in the building. The stairs in the main lobby were decorated with the sculptures of two lions (made from alabaster by A. Popel). The sculpture of "Justice" in the lobby of the left wing of the building is also his creation.

From the previous materials of ROCEM meetings it has become known to me that architect Jan Zawieyski used Roman cement in decorating the facades in 
Krakow (in particular while building the local schools) [14]. Building of the Regional Court in L'viv once again evidences the fact of architect's inclination towards the technologies with Roman cement. In this regard we would like to note that they are used in a very specific way here. Analysis shows that all plastic and sculptural decorations on façades are made from Roman cement, but besides massive rustication on parterre floor is performed in combination technique - profiled pulled frame of every plank of rustication is made from Roman cement and filled inside with a help of lime plaster, which provides the special "pecked" surface finish (fig. 5).

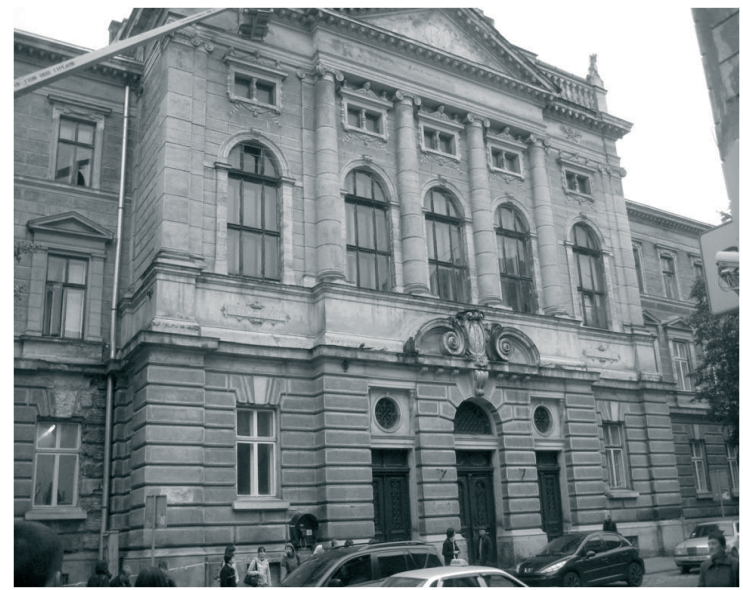

Fig. 3. The elevation of former "Palace of Justice", built with using Roman cement. The architects: Franz Skowron and Jan Zawieyski, project 1891. Foto M.Bevz, 2011.

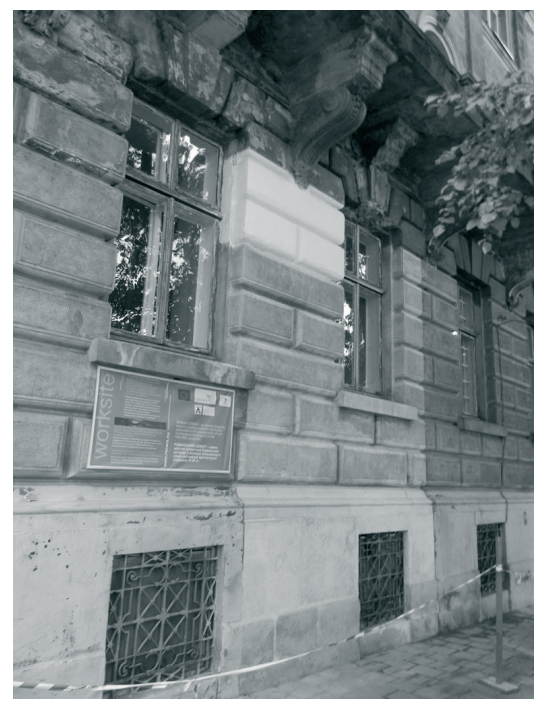

Fig. 4. The fragment of elevation of former "Palace of Justice" after the cleaning, made under promotion prof. J.Weber during the workshop in Lviv as the cooperation between the EU-FP7 project N226898 ROCARE. Aim was to demonstrate the possibility to recover the genuine appearance of the historic elevation by the use of Roman cement as historically authentic and compatible material. Executors were: Atelier Gurtner Wien (Austria) in cooperation with the restoration team of Department of Restoration of architectural Complexes of L'viv Polytechnic. August, 2011. 


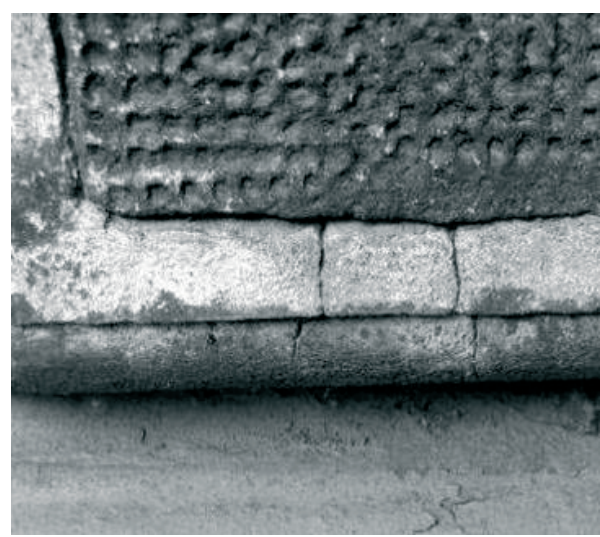

Fig. 5. The profiled pulled frame of every plank of rustication is made from Roman cement and filled inside with a help of lime plaster (on the elevation of former "Palace of Justice"). Foto M.Bevz, 2009.

The method of decoration of Provincial Court facade differs from the methods applied by Zawieyski in Krakow. In Krakow objects he often combines open brick wall with decorative elements of Roman cement - adding cornices, pilasters, window decorations $[8,14,15]$. In L'viv, we can see that technology of decoration was another and difficult.

After the World War II the building was used as educational establishment. The military service courses of L'viv Polytechnic University were conducted here. New function required significant reconstruction of building - since it was necessary to place training military equipment there. These reconstruction works were performed, and, unfortunately, they led to worsening of technical and aesthetic state of building. At present the state of building is unsatisfactory. Our pictures illustrate it. However, in the last year the military department managed to move from this historic monument and the space has been gradually occupied by civil departments of Polytechnic University. In particular, in May of the year 2008 the university administration resolved to provide the level wing of the building (basement and parterre floor) to meet the requirements of Restoration and Reconstruction of Architectural Complexes Department. Since June 2008, teachers and students have started the examination of the building and are preparing the documentation on its restoration. We are planning to establish and equip the scientific and restoration centre functioning along with the lecture halls in several restoration and educational directions, covering the problems of restoration from city planning level (regeneration of historical cities) to the level of restoration of works of art (from natural and artificial stone): Sculptures, architectural décor, from wood: art objects, including furniture; works of art from metal and so on.) Today, L'viv Polytechnic University is the only higher educational establishment in Ukraine developing the specialities of architectural restoration and restoration of works of arts.

Other objects in L'viv, where the Roman cement was applied:

Roman cement was used in 1890's while repairing the bell tower of Armenian Church (object of $16^{\text {th }}$ century) and fortifying the upper tier of the bell tower. As of today, the state of this part of the building is very good and there are no destructions of the building being observed ("Balko" Company investigation). 
Décor and sculpture from Roman cement were used during the erection of one of the most prestigious L'viv buildings of the second part of the $19^{\text {th }}$ century - building of Galician Parliament (plan by architect Juliusz Hohberger, 1877). The construction works lasted from 1877 to 1881 . Central risalit with portico on the main façade is crowned with allegoric sculptural group "Galicia, Vistula and Dniester" by sculptor T. Riger [5, p. 143-144]. Allegoric sculptures of the upper part of the building are created by Z. Trembetskyi and F. Mykulskyi. Façade is allied to Vienna Neorenaissance with opulent architectural décor. Self-disclosure of the paint on the sculpture and picturesque elements evidences the use of Roman cement (Fig. $6,7)$. In particular, we can see in on the sculpture "Education" in the left wing of the risalit and on the sculpture "Labour" in its right wing. Both compositions are created by T. Riger.

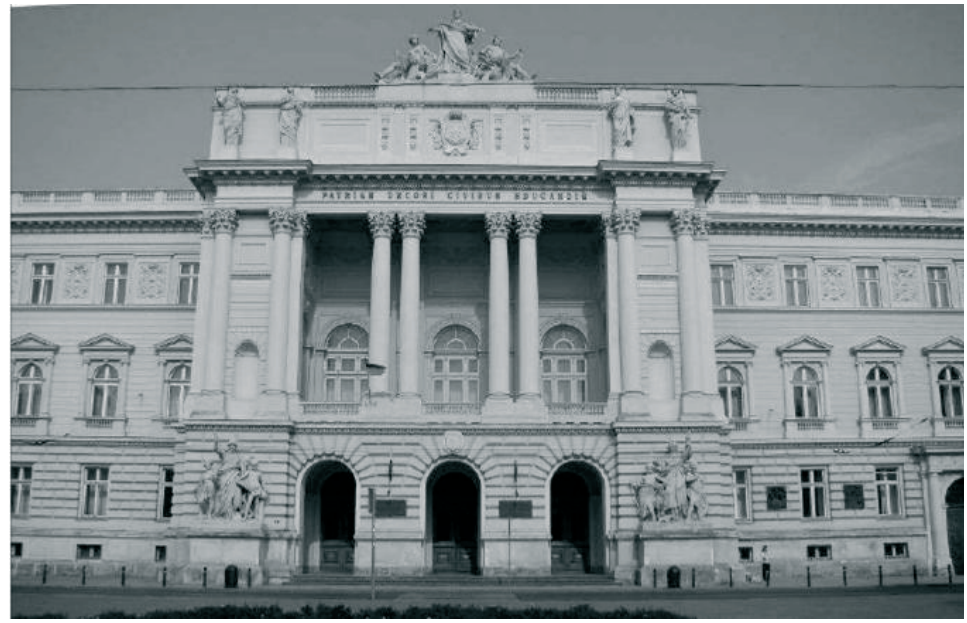

Fig. 6. The building of Galician Parliament (project by architect Juliusz Hohberger, 1877). Foto: M.Bevz, 2009.

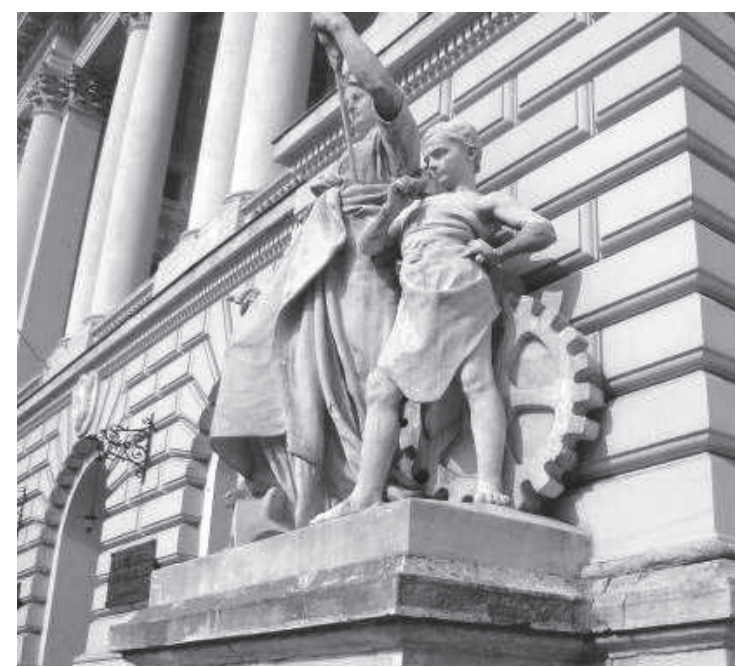

Fig. 7. The sculpture "Labour" in right wing. The composition is created by T. Riger. Foto: M.Bevz, 2009. 
Artistic works of the Opera (City) Theatre erected parallel with construction of the very theatre in 1900-1901 are characterized by opulent and well-designed Neo Renaissance façade with sculpture. All picturesque elements and sculpture here are made using Roman cement. This fact can also evidence that a part of decor and sculpture on facades of the very theatre is also made using the Roman cement technology.

The extremely plastic solution of facades of Aristocratic Casino is the creation of authors from Vienna - union of "Hermann Gottlieb Helmer and Ferdinand Fellner". The building was raised in 1897-1898. Picturesque elements and sculpture are made using Roman cement.

In Sichovykh Striltsiv Street (former Mayer's, Third May) the development of which was formed in the second part of the $19^{\text {th }}$ century, it is worth paying attention to the facades of series of building:

Neobaroque façade of building No11 by architect Karl Boublik has picturesque elements from Roman cement (fig. 8, 9). The building was raised in 1901.

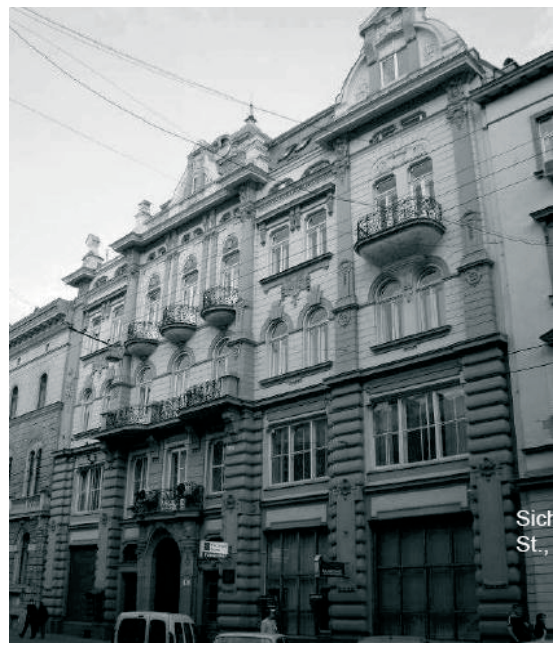

Fig. 8. The neobaroque façade of building on Sichovykh Striltsiv St. 11, architect Karl Boublik. Built 1901. Foto: M.Bevz, 2009.

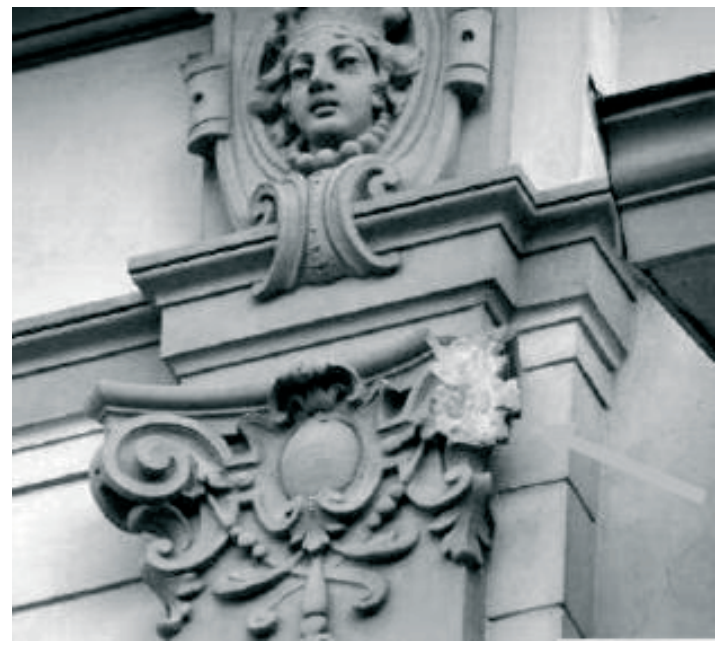

Fig. 9. The picturesque elements from Roman cement on the top part of façade of building. Foto: M.Bevz, 2009.

Next to it there is Building No 9 with can be allied to Florentine palazzo of early neo Renaissance, projected in Vienna by the union of "Hermann Gottlieb Helmer and Ferdinand Fellner" for the affiliate of Austrian-Hungarian bank. One can also observe the use of Roman cement for creation of sculptures and rustics. Authentic material is visible from the cracked modern paining.

The peculiar cracking of the surface of window frame of Building No. 13 (architect E. Keller, 1869) also evidences the probability of application of Roman cement here as well. Building No. 3 was erected in 1887 by architect V. Ravski in collaboration with L. Marconi for the Railway Directorate. Opulent décor of façade is made using Roman cement. Similar solution is implemented to the Building No. 14, which was owned by the Bank and projected in 1884 by Iulian Zakhariievych. 
The application of Roman cement can be found also in many other buildings in L'viv, both public and residential. We can see the details from Roman cement on elevations of buildings in Shevchenka avenue (fig. 10-11), Virmenska Street, Kulisha St. (fig. 12-14), Hnatiuka St., Teatralna St., Lystopadovoho Chynu St. Can look for and serve the examples of it on other buildings of central part of L'viv.

The hypothetical full list of objects built using Roman cement in L'viv (made of prof. M.Bevz on the basis of visual inspection of objects):

1. Former Palace of Fine Arts in Stryisky Park (found and identified by K.Prysyazhnyy);

2. Building of count Regional Court, on the Kniazia Romana street, 1;

3. Art Workshops Opera (the whole facade with the decoration in neo Renaissance style);

4. Bell tower of the Armenian Church: Roman cement was using during the early restoration at the beginning of Twentieth century;

5. Galician parliament building (1877, J.Hochberger, architect);

6. Building of Noble Casino, Lystopadovoho Chynu street, 6 (architects: H. G. Helmer and F. Fellner);

7-11. Buildings on the Sichovych Striltziv Street, 3 (the former Imperial Hotel); N 9 - the former Bank; N 11, 13 - Houses; N 16 - building of library

12. Bank on the corner of the T.Kostiushko street, 11 (the former Galician Regional Bank);

13. House on the Virmenska Street, 22;

14. House on the Kulisha Street, 23;

15. House on the Hnatiuka Street, 8;

16. School building on the Theatralna street, 15;

17-18. Houses on the Lystopadovoho Chynu street, 10 and 12;

18. National Museum old building, Drahomanova street, 32;

19. Greek-Catholic Cathedral of St. George (Roman cement was using during the early restoration at the beginning of Twentieth century);

20. Building of Craft School, Dudayeva street, 9;

21-35. Houses on the Str. S.Krushelnytska, N 1, 3, 5, 7, 9, 11, 13, 15, 17, 17a, 19, 21, 23, 25, 29 (villa of Yulian Zacharievich, architect);

36. The building of the Palace of the Austrian army disabled, Kleparivs'ka street;

37. The building of the palace on the Chuprynky street, 52 (information from dr. M.Kotiv);

38-40. Houses on the Franko street, 93, 96 and 104;

41. Villa of Professor C.Tullier on the Ivana Rutkovycha street, 9;

42. Villa of professor S.Ramult on the Verbytskoho street, 2;

43. House on the Kopernika street, 50;

44. Library of the L'viv Franko National University, on the Drahomanova street, 5; 
45-46. Houses on the Shchepkina street, 3 (whole facade); 5 (ground floor , 1 st floor);

47-50. Houses on the Shchepkina street, 1, 2, 4 and 6;

51. Potocki Palace on the Kopernika street, 15;

52. House on the Kotlyarevskogo street, 24;

53-54. Houses on the Brativ Rohatyntsiv street, 12 and 45;

55 . House on the Lychakivska street, 1.

56-57. Houses on the Shevchenka avenue, 26 and 28;

58. Building of Opera, Prospekt Svobody, 45a.

According information the J. Biriulow and director of the L'viv restoration-build company “ Balko" (dr. M.Cotiv) in L'viv Roman cement was produced at the last years of XIX cent. by Ivan Lewinski factory [5, p. 118]. Products came true called "L'viv stone".

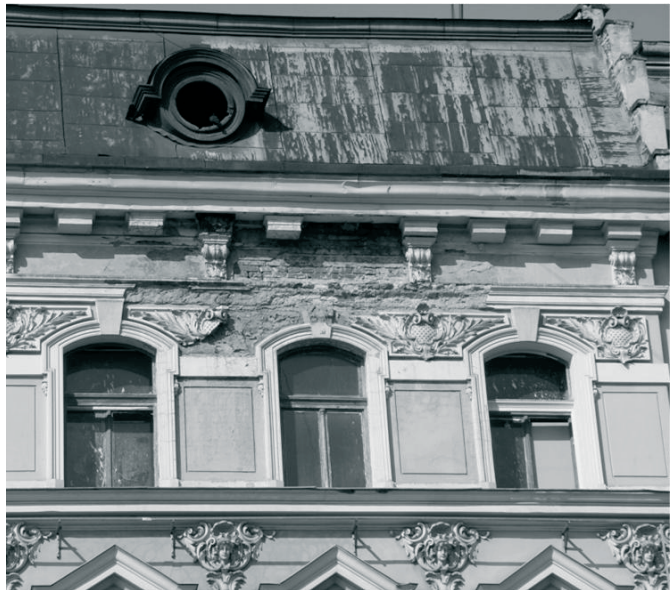

Fig. 10. The fragment of elevation of building on the Shevchenka avenue, 28. Foto: M.Bevz, 2012.

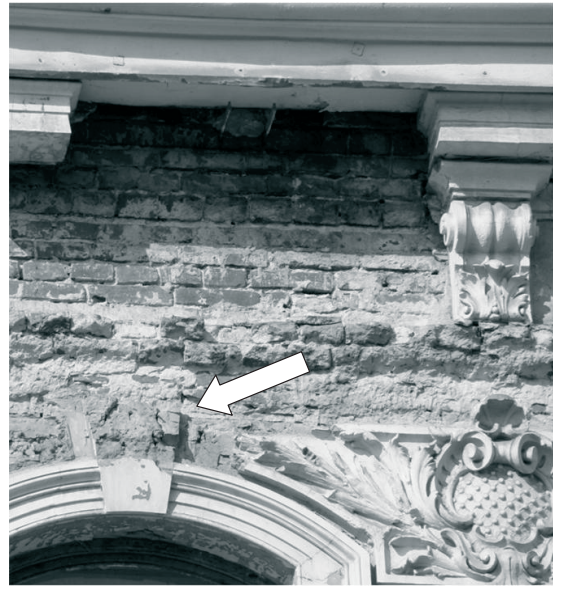

Fig. 11. The detail from Roman cement in destructive form. Foto: M.Bevz, 2012.

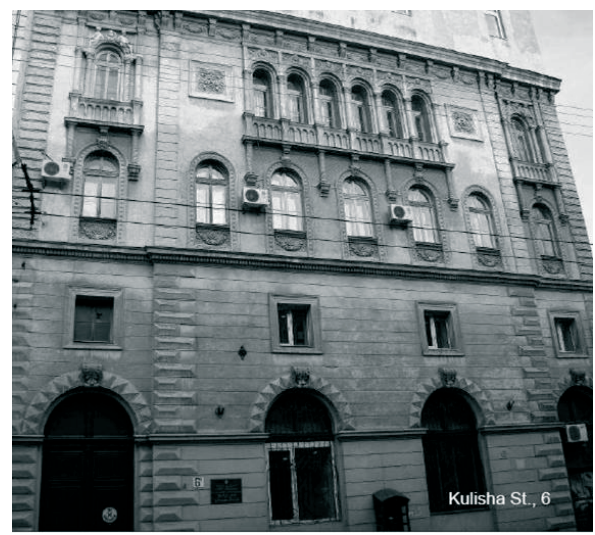

Fig. 12. The main elevation of building on Kulisha St. 6 (the art laboratory of opera). Foto: M.Bevz, 2009. 

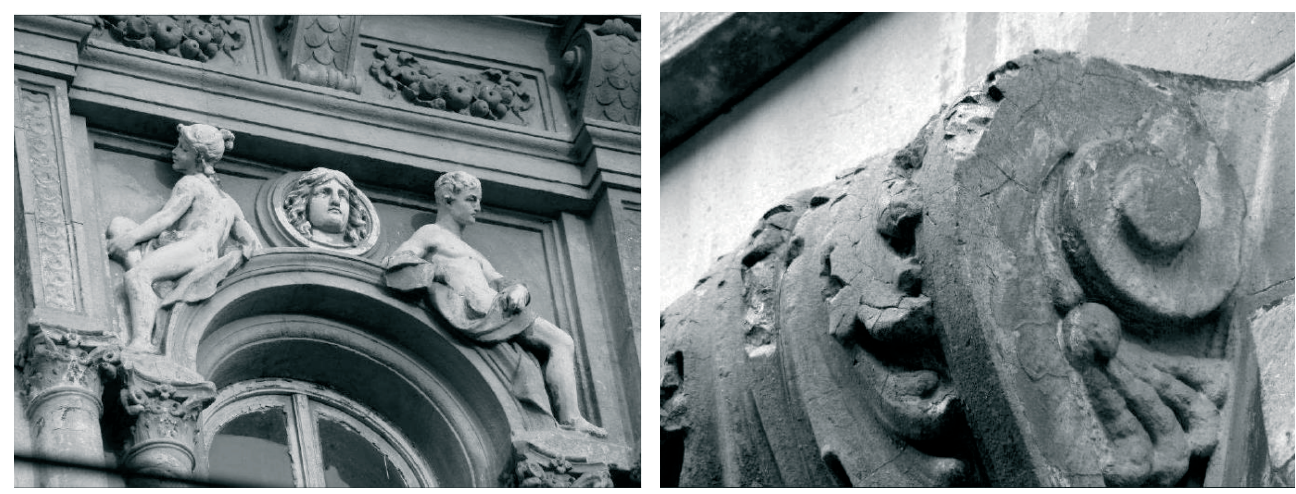

Fig. 13-14. The details from Roman cement on the elevation of the Opera art laboratory. Foto: M.Bevz, 2009.

\section{Conclusions}

1. Shown examples allow confirming that Roman cement was widely used in L'viv in the second part of the $19^{\text {th }}$ century while erecting the public and residential buildings.

2. In L'viv, no inventory and research works have been conducted till now, which would let imagine the true picture of use of Roman cement in historical buildings and evaluate the entire condition of such buildings.

3. The examples of L'viv objects with Roman cement revealed by us make it possible to ascertain what consequences are the result of use of improper methods and materials while repairing and restoring historic buildings. Unsatisfactory technical state of the majority of objects has been caused by the irregular exploitation and inappropriate materials.

4. For L'viv it is of urgency to develop a program on research, preservation and restoration of historical monuments, on which the architectural and ornamental finishing of facades was carried out with application of Roman cement.

5. The application of Roman cement may be broader than just replacing the sights on those where it was used from the beginning. It can be used in some cases to replace lost stucco decoration or sculptures on the facades of buildings, as well as for lasting copies of works of Art in the restoration and museum practice.

6. It would also conduct research in other cities of Ukraine to identify buildings erected using Roman cement. We've found several buildings in the central part of the city, the sculptural decoration are made of Roman cement. Also Roman cement was used in the construction and decoration of the palace and park complex in the village of Sharivka (build in 1881 and next years for owners from Austria: L. and J. Koenigs) in the Kharkiv region in East Ukraine. Roman cement applied for restoration of baroque town hall in Buchach during the late nineteenth or the beginning of Twentieth century.

\section{References}

[1] http://www.rocare.eu/page/start.html 
[2] Szeląg H., Skorek A. Przeszłość i przyszłość cementu romańskiego. Wiadomości Konserwatorskie. 26/2009. http://www.zeriba.pl/wk/wk26_remo-2009_02_s077-s158.pdf.

[3] Bevz M. Architectural monuments of L'viv built using Roman cement. Materials of Enduser Advisory Panel of our EU-FP7 project ROCARE - Roman Cements for Architectural Restoration to New High Standards, Project Number 226898. September, 16-17, Wien, 2009.

[4] Lubczenko W.F. Lwiwska skulptura XVI-XVII stolit. Naukowa Dumka, Kyiw, 1981, 215s.

[5] Biriulow J. Rzeźba Lwowska od połowy XVIII wieku do 1939 roku. Wydawnictwo Neriton, Warszawa, 2007, 388s.

[6] http://www.rocare.eu/page/imgt/file/8_Gurtner.pdf.

[7] http://www.rocare.eu/page/imgt/file/9_Kozlowski.pdf.

[8] http://www.rocare.eu/page/imgt/ROCAREschoolWaskaKrakowPolandWebsite.pdf.

[9] Weber J., Gadermayr N., Bayer K., Hughes D.C., Kozłowski R., Stillhammerova M., Ullrich D., Vyskocilova R. Roman cement mortars in Europe's architectural heritage of the 19th century. Journal of ASTM International 4(8) (2007) Paper ID JAI100667.

[10] Adamski G., Bratasz L., Mayr N., Mucha D., Kozlowski R., Stillhammerova M., Weber J. Roman Cement - Key historic material to cover exteriors of buildings. in: Repair mortars for historic masonry. Proceedings pro067 RILEM TC 203-RHM, 2009, pp. 2-11.

[11] http://lp.edu.ua/node/605.

[12] Lewicki J. Między tradycja i nowoczesnoscia. Architektura Lwowa lat 1893-1918. Wydawnictwo Neriton, Warszawa, 2005, 590s.

[13] Architektura Lwowa. Czas i styli. Centr Europy, Lwiw, 2009, 760s.

[14] http://www.rocare.eu/page/imgt/file/rocare-manual_low-res\%20\%282b\%29.pdf.

[15] Purchla J. Jan Zawiejski - architekt przełomu XIX i XX wieku. PWN, Warszawa, 1986.

\title{
Problem ochrony i restauracji zabytków architektonicznych Lwowa, zbudowanych $\mathrm{z}$ użyciem cementu romańskiego
}

\begin{abstract}
Mykola Bevz
Katedra Konserwacji Zabytków, Wydziat Budownictwa i Architektury, Politechnika Lubelska, e-mail:m.bevz@pollub.pl
\end{abstract}

Streszczenie: W artykule przedstawiono przykłady potwierdzające, powszechne zastosowanie cementu romańskiego we Lwowie w drugiej połowie 19 wieku podczas wznoszenia budynków użyteczności publicznej i mieszkalnych. Uzasadnia się konieczność tworzenia i rozwijania specjalnego programu skierowanego na inwetaryzacja i badania obiektów, sprecyzowanie metody konserwacji i restauracji architektonicznych zabytków, posiadających elementy architektoniczne i dekoracyjne wykonane z cementu romańskiego.

Słowa kluczowe: cement romański, zabytki architektury, konserwacja i restauracja. 